\title{
The Pedagogy of Corpus-aided English-Chinese Translation from a Critical \& Creative Perspective
}

\author{
Qingliang Meng \\ College of Applied Technology, Jiaxing University, Jiaxing, China; \\ School of Languages, Cultures and Linguistics, University College Dublin, Dublin, Ireland
}

\begin{abstract}
With the advancement of corpus linguistics, there has been an increasing interest in using corpora as a tool for translator training and translation practice. Despite the usefulness of corpora in translation pedagogy, the more and more reliance on parallel corpora in translating activities has diminished the ability to determine the meaning of words within different contexts using dictionaries. However, it has hampered the enhancement of translation competence of trainee translators. This study investigates the necessity of adopting critical and creative thinking in the teaching of corpus-aided English-Chinese translation. It first examines the increasing importance of corpora in aiding translator training and translating practice. A critical analysis was adopted to analyze a translation case using a parallel corpus. Thirteen Chinese versions of Pride and Prejudice's opening remark were compared and analyzed critically and creatively with the aid of different corpora. Pedagogical implications for translation teaching were summarized.
\end{abstract}

Index Terms — critical, creativity, translation, pedagogy, corpus, English, Chinese

\section{INTRODUCTION}

The combination of corpus linguistics and Descriptive Translation Studies (DTS) has given rise to Corpus-based Translation Studies (CTS). Many different corpora types, such as monolingual, parallel, comparable corpora, have been built and applied in translation studies (Zanettin, 1998). According to Laviosa (2004), Gellerstam's first monolingual comparable corpus of Swedish novels in 1986 and Lindquist's investigation of Swedish renderings of English adverbials with a parallel language database in 1989 marked the beginning of applied corpus translation studies, which was mainly concerned with the practice and training of translators (Laviosa, 2004, p.15). Laviosa also pointed out that corpora in applied CTS are used as sources for the retrieval of translation equivalents to help improve the quality and efficiency of target texts. Moreover, it functions as "repositories of data" for better understanding of the translation process and language behavior (ibid.). Unlike descriptive studies, which mainly use parallel, comparable monolingual corpora as well as single translational corpora for a description of translation process and product, applied CTS rely primarily on comparable bilingual corpora or monolingual target language corpora in experiments or classroom teaching of translation to enhance the acquisition of translation skills and target language competence (Laviosa, 2002, p. 101).

As a new paradigm of translation research, Chinese scholars have already adopted corpus linguistics and applied to their studies. Liu Kanglong \& Mu Lei (2006) explored the relationship between corpus linguistics and translation studies. Hu Xianyao (2007) discussed the characteristics of lexical terms in Chinese translated novels based on corpora. Xiong Bing (2015) studied a translation teaching model based on an English-Chinese parallel corpus, and Xu Jiajin(2016) looked at the semantic generalization of translational English based on comparable corpora. However, Malmkjær warned that the bulk of statistical evidence, like corpora's concordances, may lead scholars to neglect or ignore problematic translation (Baker, 1998, p. 53). The novice translators, who have not yet developed proficient linguistic ability and translation competence, might rely too much on corpora to produce the target texts without appropriate guidance from the teachers or trainers. Therefore, it is quite essential and necessary for both teachers and students to assume critical and creative thinking in corpus-aided translation. The masterpieces of translation are mostly the result of the translators' creativity, and "creativity in translation starts where imitation stops" (Newmark, 1991, p. 9).

This paper first reviewed the importance of corpora in translation pedagogy. Then, a comparison was made between dictionaries and corpora in translation, followed by a discussion of creativity as an essential quality of translators. Afterward, a statistical investigation into parallel and monolingual corpora was conducted. The pedagogical implications for translation teaching and practice were summarized in the last section.

\section{IMPORTANCE OF CORPORA IN TRANSLATION TRAINING AND PRACTICE}

\section{A. Application of Corpora to Translation Studies}

The development of computer technology has made possible the automatic processing of large-scale information. When such technology is applied to collecting texts representing a given language for linguistic analysis, a new branch 
of general linguistics called corpus linguistics came into being. Modern corpus linguistics began in the early 1960s, marked by the creation of Brown Corpus (Laviosa, 2002, p. 3). After nearly thirty years of progress, Sinclair (1992) predicted that there would be "some fascinating years and decades in linguistics" based on the development of computer technology which enables people to retrieve information from text corpora, and he firmly believed that such technology would exert the most profound effect in the study of language (Sinclair, 1992, p. 379). Following Sinclair's prediction, Baker (1993), based on her in-depth knowledge and rich experience in the field of translation studies, argued that "the techniques and methodology developed in the field of corpus linguistics will have a direct impact on the emerging discipline of translation studies, particularly to its theoretical and descriptive branches" (Baker, 1993, p. 233). At almost the same time, Leech (1994) also proclaimed that "In the future,...the grammatical tagging of such large quantities of data is likely to have important applications" (Leech et al., 1994, p. 47). A quarter-century has passed since then, corpus linguistics has not only grown into a fully-fledged discipline in itself but been widely adopted by scholars in the field of translation studies in their research of various kinds. Furthermore, this trend had encouraged Robin et al. (2017) to claim that the spread of computer-readable electronic corpora has enabled researchers to apply corpus-based approaches to examine translated texts (Robin et al., 2017, p. 100).

\section{B. Use of Dictionaries and Corpora in Translator Training and Translation Practice}

One of the primary resources used by translators or translation trainers has been printed dictionaries (Bowker, 2000, p. 186). Dictionaries have long been the most important source of consultation for translators, regardless of professional translators or novice translators. An authoritative dictionary usually provides as many entries as possible, enabling the translators to find the equivalent meaning of some difficult words or phrases in rendering the target texts. A professional translator may use the dictionary entries as a clue to produce the closest equivalents in the target language, whereas novice translators tend to replace the words or phrases in the source langue with the entries in the dictionaries mechanically. However, due to such shortcomings as limited space, the omission of terms or the lack of extended contexts, traditional dictionaries have apparent limitations in providing services to translators. The advent of corpora has changed the situation. With corpus linguistics being applied more and more widely to translation training and evaluation from the early 1990s, corpora have become "a useful complement to conventional translation resources" (Bowker, 1999, p.170). From dictionaries to the Internet and corpora, translators are relying more and more heavily on external sources. Compared with dictionaries, "corpora can provide greater coverage of the concepts and terms in a subject field," and usage information can easily be obtained from a corpus consisting of authentic running texts written by subject field experts (Bowker, 2000, p. 187). What is more, "Corpora are also capable of providing information about the relative frequency of lexical items-information that is not typically provided in a dictionary even though it can be precious to translators" (Williams, 1996, p.290, cited from Bowker, 2000, p. 188).

While contending that Evaluation Corpus can significantly reduce the subjective element in the evaluation of translation product, Bowker also reminds that a corpus should not be taken "as a replacement for competence and critical judgment on the part of the evaluators, but rather as an aid to help them make sound and objective judgments" (Bowker, 2000, p. 206). This is a significant and timely reminder based on the fact that the application of corpus linguistics to translator training and translation studies seems to have been deemed as a fashionable approach, which has neglected the significance of laying a solid foundation for novice translators. However, when emphasizing the objectivity of corpora in identifying lexical errors made by student translators, Bowker (2000, p.199) hypothesized that corpus-based feedback would be more convincing and acceptable to students, which would "result in the production of higher quality translations." It should be pointed out that corpus-based feedback alone is insufficient to enhance students' competence in rendering high-quality translations. Some concordances in target language found in some parallel corpora might not be the closest or appropriate equivalents judging from contextual or cultural criteria.

To sum up, both translation teachers and students must be wise in using dictionaries and corpora. Dictionaries provide entries and explanations, while corpora offer more examples and broader context, which complement each other. Translation teachers or trainers, in particular, should assume critical and creative thinking in their daily training practice with corpora.

\section{CRITICAL AND CREATIVE THINKING IN CORPUS-AIDED TRANSLATION}

\section{A. Creativity in the Translation Process}

People with little knowledge of translation tend to believe that translation is no more than finding the equivalents of the source language in the target language, retaining the meaning and style at the same time. For translation practitioners, it is not the case at all. Critical and creative thinking plays a crucial role in producing masterpieces of translation, and in some sense, creativity in translation is more complicated than in creative writing. As early as the 1970s, Preiser(1976, p. 2f) had already proposed such characteristics of creativity in translation as a novelty, surprising elements, singular or at least unusual, and the fulfillment of particular needs by fitting in with reality (quoted from Kussmaul, 1995, p. 39). According to Kussmaul, despite general discussion of creativity by such scholars as Wilss, who maintained that creative translation involves "unpredictable non-institutionalized use of language" (Wilss, 1988, p.127, quoted from Kussmaul, 1995, p. 39) and Alexieva, who believed that creative translation is a non-rule-governed selection of translation variant (Alexieva, 1990, p. 5, quoted from Kussmaul, 1995, p. 39), there had been no data-based 
study in this respect until then, limiting his research to non-routine processes which give rise to problems that require creative solutions (Kussmaul, 1995, p. 39). Aranda maintained that although "creativity is an inevitable aspect of the translation process" involving "problem-solving" at an individual level, it has been "a neglected research topic in translation studies" (Aranda, 2009, p. 23) with scarce attention from the field of translation studies. The significance of creativity in translation lies in the fact that it introduces new concepts, new genres, and new devices and mirrors the shaping power of one culture on another (Aranda, 2009, p. 30). Kisiel (1990) had gone a step further, contending that translation is by no means "a seemingly slavish repetition" but "a creative repetition" that requires tact, boldness, and ingenuity, especially when none of the entries offered in the dictionary can fit the sense of the word used in the source text (Kisiel, 1990, p. 143-144). He thus regards the translator's task as "more difficult than that of the original author" (Kisiel, 1990, p.144). From a translator training perspective, Hewson (2016, p. 20) defined creativity as:

the ability to exploit the resources of both source and target languages to produce unpredictable micro-level translation solutions that are coherent with the macro-level interpretation given to the text and compatible with external parameters.

He also claimed that creativity had rarely been explored in many general works on translation theory despite that creative approaches were frequently adopted by translation practitioners, especially in dealing with challenging texts in whatever fields. Furthermore, it was seldom studied in translation classrooms (Heuson, 2016, p. 23). Translation pedagogy generally focuses on principles, routines, norms, techniques, and technologies. In translated works, particularly literary translations, creativity differentiates an excellent translator from a mediocre translator, a masterpiece of translation from a commonplace one.

\section{B. Critical and Creative Thinking in Corpus-aided Translation}

As mentioned above, dictionaries and corpora, which complement each other, constitute primary consultation sources for translators. "Bilingual dictionaries provide normative translation solutions for lexical items, which are incorporated into standard syntactic patterns and governed by 'correct' grammatical usage" (Hewson, 2016, p. 14), while concordance tools enable translators to "see terms in a variety of contexts simultaneously" and frequency information can help translators to determine commonly or idiosyncratically used particular terms (Bowker, 1999, p.162;163 ). Therefore, corpora are "a useful complement to conventional translation resources" (Bowker, 1999, p. 170) in the real sense.

However, we should never overestimate the role of corpora in facilitating translating activities. While emphasizing the central role of corpus translation studies for the discipline of Translation Studies to remain vital and move forward, Tymoczko (1998, p. 1) suggested that "intuition and human judgment" are still essential components behind the establishment of corpora, which is no different from the design of any experiment or research program or survey. Therefore, translation practitioners and teachers must know that neither dictionaries nor corpora can replace translation competence, consisting of linguistic and extra-linguistic components. We should take advantage of technological advances in language and translation studies to gain access to a wide range of authentic and suitable texts. This would not only enable the trainers to verify or correct the students' choices, both conceptual and linguistic, but provide more constructive and objective feedback based on the evidence (or lack thereof) in the corpus. Moreover, input enhancement through intensive exercises is always necessary and indispensable for nurturing language awareness and promoting linguistic competence in novice translators.

To assume critical and creative thinking in corpus-aided translation, we should:

i. make use of the large number of concordances found in the parallel or monolingual corpora to set exercises for student translators;

ii. apply translation norms acquired previously to make comments on and analysis of a few typical examples in the parallel corpora;

iii. mobilize human judgment and creative thinking to improve some target texts.

In this way, corpus linguistics will be given full play in translation teaching and practice. In the following part, an example taken from a paper entitled "The Role of 'highly refined' parallel corpora in translation teaching" in the Journal of Chinese Translators was analyzed. First, we would like to express our thankfulness to the author. Second, it should be noted that the analysis was by no means a denial of the use of corpus by the author. On the contrary, this paper provided an excellent example of utilizing corpora in translator training. In this paper, the author illustrated the application of the parallel corpus "English-Chinese and Chinese-English Translation Distant Teaching System" developed by the City University of Hong Kong to her classroom teaching of translation. The source passage in the corpus is:

\section{(SL)KPMG could transform into a global partnership in 10 years}

The head of KPMG has forecast that the accounting firm could transform into a single global partnership within ten years.

The radical reform would be a lasting solution to regulators' concerns that the big accounting firms offer inconsistent audit work standards across the world.

Mike Rake, the international chairman of KPMG, said the creation of a single global would.

The Chinese version given in the corpus is as follows: 
(TL)毕马威可能在 10 年内转成单一全球合伙企业

bì mă wēi kě néng zài shí nián nèi zhuăn chéng dān yī quán qiú hé huǒ qĩ yè.

会计师事务所毕马威（KPMG）全球业务董事长麦克·雷克（Mike Rake）近日预言说，公司可能在

kuài jì shī shì wù suǒ KMPG quán qiú yè wù dǒng shì zhăng Mike Rake jìn rì yù yán shuō, gōng sī kě néng

10 年内转型成单一全球合作企业。

zài shí nián nèi zhuăn chéng dān yī quán qiú hé zuò qĩ yè.

监管部门一直担心，大型会计师事务所在全球提供的服务标准不一致，而上述根本性的改革将一劳

jiān guăn bù mén yī zhí dān xīn, dà xíng kuài jì shī shì wù suǒ zài quán qiú tí gōng de fú wù biāo zhǔn bù yī zhì, ér shàng shù gēn běn xìng găi gé jiāng

永逸地解决这一问题。

ȳi láo yǒng yì de jiě jué zhè yī wèn tí.

雷克先生表示, 单一合伙人制度的确立将......

Rake xiān sheng biăo shì, dān yî hé huǒ rén zhì dù de què lì jiāng......

The teacher first asked the students to compare the two versions and found that the second paragraph's theme-rheme structures differed in the source and target languages. Then, by clicking the tagging mark, students found the detailed analysis of translation strategies, through which they learned the theme-rheme structures in both English and Chinese texts, and were better informed of the effect of the theme-rheme system on the cohesion and coherence of the context. After that, the teacher suggested that the students produce their own version, which read as follows:

$(\mathrm{S})$ 这一根本性改革将一劳永逸地解除监管部门的忧虑, 监管部门一直担心大型会计师事务所在全球提供的审 计标准不一致。

zhèyī gēn běn xìng găi gé jiāng yī láo yǒng yì de jiě chú jiān guăn bù mén de yōu lù̀, jiān guăn

bù mén yī zhí dān xīn, dà xíng kuài jì shī shì wù suǒ zài quán qiú tí gōng de fú wù biāo zhǔn bù yī zhì.

Based on the knowledge of the theme-rheme structure and the two different versions of the second paragraph, the teacher asked the students to discuss in groups, and most students believed that the student version read more fluently. After analyzing the differences between the two languages, the teacher pointed out that the target text's information distribution was not in line with the Chinese way of expression. In contrast, the information distribution in the target text in the corpus has been adjusted based on the Chinese logic sequence, which was more acceptable in terms of Chinese readers' expectations. The teacher finally summarized that the comparison between the two versions further indicated the interactive relationship between the selection of theme-rheme structure and textual coherence. The above is undoubtedly an excellent case of applying parallel corpora to teaching. Students were motivated and encouraged to produce their version. However, critical and creative thinking led us to challenge this approach and doubt whether there was still room for improvement in the target text. When we took a closer look at the sentence in question in the target text, we found that in the source language, the topic of the first paragraph was the transformation of the firm that could happen within ten years, and this is followed by "the radical reform" at the beginning of the second paragraph, realizing a cohesion and making the sentence read smoothly. Whereas the corresponding Chinese version of this paragraph begins with "The regulators are concerned" through back translation, which was not mentioned in the first paragraph, thus failing to achieve cohesion and sounded a bit abrupt. From this perspective, it is not a good translation either.

Based on the version in the parallel corpus and the student's rendering, we'd like to propose the following version of the sentence in question as follows:

这一根本性改革将一劳永逸地解决监管机构所关切的大型会计师事务所在全球提供的审计标准不一致的问 题。

zhè yī gēn běn xìng găi gé jiāng yī láo yǒng yì de jiě jué jiān guăn bù mén suǒ guān qiè de dà xíng kuài jì shī shì wù suǒ zài quán qiú tí gōng de fú wù biāo zhǔn bù yī zhì de wèn tí.

This version avoided the other versions' problems, achieving cohesion and introducing new information "regulators" smoothly. It is, therefore, assumed to be a better version. Maybe we are somewhat captious in this very tiny aspect. Instead of criticizing, it is suggested that when applying specific corpora to the teaching of translation or translation practice, it had better adopt human judgment by assuming critical and creative thinking rather than taking the offerings of the corpus blindly. We should mobilize our knowledge of and experience in translation to produce better versions, which will enhance the student translator competence more effectively and improve the quality of existing corpora.

\section{METHODOLOGY}

\section{A. Materials}

The research was designed to illustrate the significance of critical and creative thinking in corpus-aided translation practice. The well-known opening paragraph of Pride and Prejudice by Jane Austin was taken as an example. Its thirteen Chinese versions of different periods by different translators were compared and analyzed.

As a romantic novel, Pride and Prejudice was first published in 1813 and has gained tremendous popularity among Chinese readers since it was translated and introduced into China. The opening remark, "It is a truth universally acknowledged that a single man in possession of a good fortune must be in want of a wife," has not only become a 
household sentence in everyday expressions but also remained a hot topic in the field of literature, marriage, love, and family, etc. Researchers like Wang Yan (2007, p. 100) used the novel as a corpus to study linguistic characteristics, plot development, and character personalities with such tools as WordSmith. However, almost no endeavor has been made to compare their differences based on the analysis of relevant corpora, not to mention applying corpus analysis to translation practice and translator training. In translator training, comparable bilingual corpora are often employed to explore stylistic features of texts by comparing words and phrases with strong formal resemblance (Laviosa, 2002, p. 102). Sometimes, translators also use bilingual corpora to produce better target texts based on the equivalents of the same words or phrases. In such cases, corpora play a similar role in dictionaries, with the differences lying in a larger number of examples and extended contexts. In this research, The Babel English-Chinese Parallel Corpus was used as a reference for evaluating the quality and differences of target texts produced by different translators. This corpus was created on a research project Contrasting English and Chinese consisting of 327 English articles and their translations in Mandarin Chinese. It contains 121,493 English tokens plus 135,493 Chinese tokens from 115 texts collected from the World of English between October 2000 and February 2001, and 132,140 English tokens plus 151,969 Chinese tokens from 212 texts selected from Time from September 2000 to January 2001. The corpus contains 544,095 words, including 253,633 English words and 287,462 Chinese tokens, from such articles as The Future of Africa, My Only True Love, For Whom The Bell Tolls, Hacking the Cell's Circuitry, Blue Sky Still Out There, etc.. Although this is not a purely literary corpus, it is large enough with comprehensive coverage and representativeness because the language of Pride and Prejudice is not difficult and can be read with relative comfort even it was written more than two hundred years ago.

Furthermore, general corpora such as BNC, COCA, COHA, and MCC (Modern Chinese Corpus) will also address the above parallel corpus' deficiencies. According to Laviosa (2002, p.103), general corpora can also have equal value for enhancing translator skills and refinement of contrastive knowledge of the source and target language. BNC is the British National Corpus with 100 million word collections of written and spoken language from a wide range of sources, designed to represent a broad cross-section of British English from the late twentieth century. COCA is the Corpus of Contemporary American English, containing more than 560 million words of text (20 million words each year 1990-2017), equally divided among spoken, fiction, popular magazines, newspapers, and academic texts. MCC (www.cncorpus.org) is the corpus developed and maintained by the Chinese National Committee of Language and Characters, containing 19,455,328 tokens (including Chinese characters, letters, figures, and punctuations), 12,842,116 words (including single Character words, multi-character words, letter words, foreign words, the string of figures, punctuations), 162,875-word types in total, and 151,300 Chinese words (excluding foreign words, a string of figures and punctuation) from 9,487 texts selected from books, book chapters, journal and newspaper articles, etc.

\section{B. Data Collection}

The method of comparison was adopted to compare the thirteen versions of the opening remark of

Pride and Prejudice primarily focusing on keywords and phrases such as "truth," "must," and "be in want of," etc. Before the comparison, the information about the translators, publishing houses, the publication time, and the number of Chinese characters of each target text were collected. Then based on the results of the comparison, the Chinese equivalents of "truth," "must," and "be in want of" were listed to find out the differences. To have a clear picture of the differences in translation renderings, back translation from each Chinese version into English was provided. Concordance and Word Sketch were used to study more examples of the usage of the words and phrases mentioned above through Sketch Engine to observe their meaning within broader contexts and more examples.

During this process, the comparable bilingual corpora such as The Babel English-Chinese Parallel Corpus, and the monolingual corpora such as BNC, COCA, COHA, and MCC were used as sources to extract the usage of the keywords and phrases contained in the sentence of the question, as if we were looking at the collocations, the contexts and styles with an amplifier to see the exact meaning of these words and phrases more clearly to evaluate the quality of translated products by each translator. The table below (Table 1) shows the thirteen versions during the past sixty years from the 1950s to 2016. About half of the translators are professors from universities, which indicates that they had an excellent mastery of both English and Chinese languages. However, the target texts vary a lot in the diction of several keywords and phrases. 
TABLE 1 (BELOW)

\begin{tabular}{|c|c|c|c|c|c|}
\hline A & B & $\mathrm{C}$ & D & E & $\mathrm{F}$ \\
\hline Translator & Publishing House & Time & $\begin{array}{l}\text { It is a truth universally acknowledged, that a single man in possession of a good fortune } \\
\text { must be in want of a wife. }\end{array}$ & $\begin{array}{c}\text { Number of } \\
\text { Chinese } \\
\text { Characters }\end{array}$ & Note \\
\hline \multirow[t]{2}{*}{ Wang, Ke Yi } & \multirow[t]{2}{*}{ Shang Hai Yi Wen } & \multirow[t]{2}{*}{1980} & 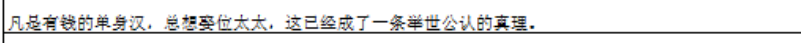 & \multirow[t]{2}{*}{28} & \multirow{2}{*}{$\begin{array}{l}\text { Finished in } \\
\text { the } 1950 \text { s. }\end{array}$} \\
\hline & & & Fanshi you qqian de danshen han, zong xiang qu wei taitai, zhe yijing cheng le yi tiao jushigongren de zhenli. & & \\
\hline \multirow{2}{*}{ Sun, Zhi Li } & \multirow{2}{*}{ Yi Lin } & \multirow{2}{*}{1990} & 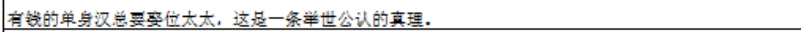 & \multirow{2}{*}{23} & \\
\hline & & & You qian de danshen han zong yao qu wei taitai,zhe shi yi tiao jushigongren de zhenli. & & \\
\hline \multirow[t]{2}{*}{$\begin{array}{l}\text { Zhang Ling } \\
\text { Zhang Yang }\end{array}$} & \multirow{2}{*}{ People's Literature Publishing House } & \multirow{2}{*}{1993} & 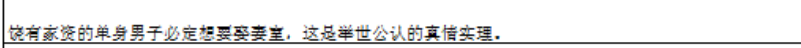 & \multirow[t]{2}{*}{27} & \\
\hline & & & Rao you jia zi de danshen nan zi biding xiang yao qu qishi, zhe shi jushigongren de zhenging shili. & & \\
\hline \multirow[b]{2}{*}{ Yi Hai } & \multirow[b]{2}{*}{ Hai Xia Literature \& Art PH } & \multirow[b]{2}{*}{1994} & 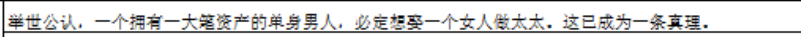 & \multirow[b]{2}{*}{37} & \\
\hline & & & $\begin{array}{l}\text { Jushigongren, yi ge yongyou yi dabi zichan de danshen nanren, bi ding xiang qu yi ge nv ren zuo taitai. } \\
\text { Zhe yi cheng wei yi tiao zhenli. }\end{array}$ & & \\
\hline \multirow{2}{*}{ Zhang, Jing $\mathrm{H}_{2} \mathrm{O}$} & \multirow{2}{*}{$\begin{array}{l}\text { China Translation \& } \\
\text { Publishing Corporation }\end{array}$} & \multirow{2}{*}{2009} & 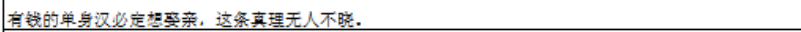 & \multirow{2}{*}{19} & \multirow{2}{*}{$\begin{array}{l}\text { Finished } \\
\text { in } 1995 .\end{array}$} \\
\hline & & & You qian de danshen han bi ding xiang qu qin, zhe tiao zhenli wu ren bu xiao. & & \\
\hline \multirow[b]{2}{*}{$\mathrm{Li}$, Chang Shuan } & \multirow{2}{*}{$\begin{array}{l}\text { Foreign Language } \\
\text { Teaching \& Research }\end{array}$} & \multirow[b]{2}{*}{1997} & 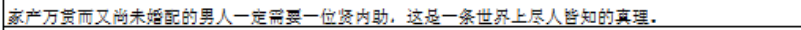 & \multirow[b]{2}{*}{37} & \\
\hline & & & $\begin{array}{l}\text { Jia chan wanguan er you shang wei hunpei de nan ren yi ding xu yao yi wei xian nei zhu, zhe shi yi tiao shijie } \\
\text { shang jin ren jie zhi de zhenli. }\end{array}$ & & \\
\hline \multirow{2}{*}{ Fan, Qing Lan } & \multirow{2}{*}{ SDX Joint Publishing } & \multirow{2}{*}{2010} & 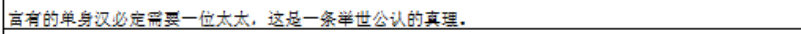 & \multirow{2}{*}{25} & \\
\hline & & & Fu you de danshen han bi ding xu yao yi wei taitai, zhe shi yi tiao jushigongren de zhenli. & & \\
\hline \multirow[b]{2}{*}{ Wang, Jin Hua } & \multirow[b]{2}{*}{ Bei Yue Literature \& Art } & & 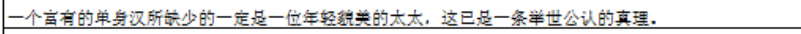 & & \\
\hline & & 2011 & $\begin{array}{l}\text { Yi ge fu you de danshen han svo que shao de yi ding shi yiwei nianging maomei de taitai,zhe yi shi yi tiao } \\
\text { jushigongren de zhenli. }\end{array}$ & 36 & Compilation \\
\hline Lvo, Liang Gong & Yangtz Literature \& Art & 2011 & 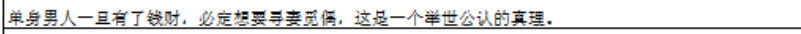 & 29 & Finished \\
\hline & & & Dan shen nan ren yi dan you le qiancai, bi ding xiang yao xun qi mi ov, zhe shi yi ge jushigognren de zhenli. & & \\
\hline & & & 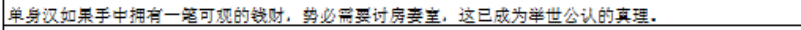 & & \\
\hline Fang, Hua Wen & Shang Hai Yi Wen & 2011 & $\begin{array}{l}\text { Dan shen han ru guo shou zhong yong you yi bi ke guan d qian cai, shi bi xu yao tao fang qi shi, zhe yi } \\
\text { cheng wei jushigongren de zhenli. }\end{array}$ & 35 & \\
\hline Zhang, Chen Guan & $\mathrm{J}_{\mathrm{i}} \mathrm{L}$ in & 2013 & 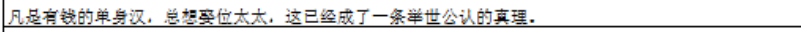 & 28 & \\
\hline & & & Fan shi you qian de danshen han, zong xiang qu wei taitai, zhe yijing cheng le yi tiao jushigongren de zhenli. & & \\
\hline Gro, Zhi Hong & Bai Hua Zhow Literature \& Art & 2013 & 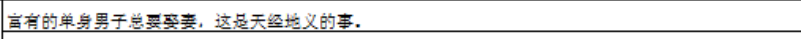 & 19 & \\
\hline & & & Fu you de danshen nan zi zong yao qu qi, zhe shi tianjingdiyi de shi. & & \\
\hline$\pi+\pi+8$ & 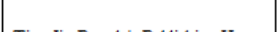 & menct & 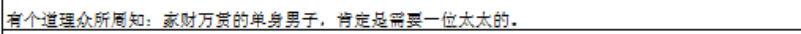 & & \\
\hline $\mathrm{Li}$, Ji Hong & Tian Jin People's Publishing House & 2016 & $\begin{array}{l}\text { You ge daoli zhong suo zhou zhi: jia cai wan guan de dan shen nan zi,ken ding shi } \\
\text { xu yao yi wei taitai de. }\end{array}$ & 27 & \\
\hline
\end{tabular}

From the table above, we got the proportion of each equivalent of "truth," "must," and "be in want of" produced by different translators (Graph 1, below).

EQUIVALENTS OF “TRUTH”

\begin{tabular}{lccc}
\hline 真理 (zhēn lǐ) & 真情实理 (zhēn qíng shí lǐ) & 天经地义(tiān jīng dì yì) & 道理(dào li) \\
10 & 1 & 1 & 1 \\
$77 \%$ & $7.7 \%$ & $7.7 \%$ & $7.7 \%$ \\
\hline
\end{tabular}

EQUIVALENTS OF "MUST"

\begin{tabular}{|c|c|c|c|c|}
\hline 总 (zǒng) & 必定(bì dìng) & 一定(ȳ̄ dìng) & 势必 (shì bì) & Total \\
\hline 4 & 5 & 3 & 1 & 13 \\
\hline $31 \%$ & $38 \%$ & $23 \%$ & $7.7 \%$ & $100 \%$ \\
\hline
\end{tabular}

EQUIVALENTS OF "BE IN WANT OF”

\begin{tabular}{lccc}
\hline 想/想要 (xiăng/xiăng yào) & 需要 $(x \bar{u}$ yào) & 要 (yào) & Total \\
6 & 4 & 2 & 13 \\
$46 \%$ & $31 \%$ & $15 \%$ & 1 \\
\hline
\end{tabular}

Here, ten out of thirteen equivalents of "truth" are 真理 (zhēn lǐ), accounting for $77 \%$ of the total. The equivalents of “must” are distributed relatively evenly, with four 总 (zǒng), 31\% of the total, five 必定(bì dìng),38\%, while 一定(y1̄ dìng) and 势必 (shì bì), accounting for 23\% and 7.7\% respectively. As per the phrase "be in want of," six translators rendered it as 想/想要 (xiăng/xiăng yào), nearly half of the total, while 需要(xū yào), 要 (yào), and 缺少(quē shăo) accounting for $31 \%, 15 \%$, and $7.7 \%$ respectively. Which of the equivalents rendered by the translators in different periods has the closest meaning to the original? Is the equivalent of the highest proportion the best one? If not, what might be the better equivalent? We tried to answer these questions in the following section with the help of corpora.

\section{Results and Discussion}

The equivalent of "truth."

We first searched for the word "truth" in The Babel English-Chinese Parallel Corpus, and 17 matches were returned. (Graph 2, below) 


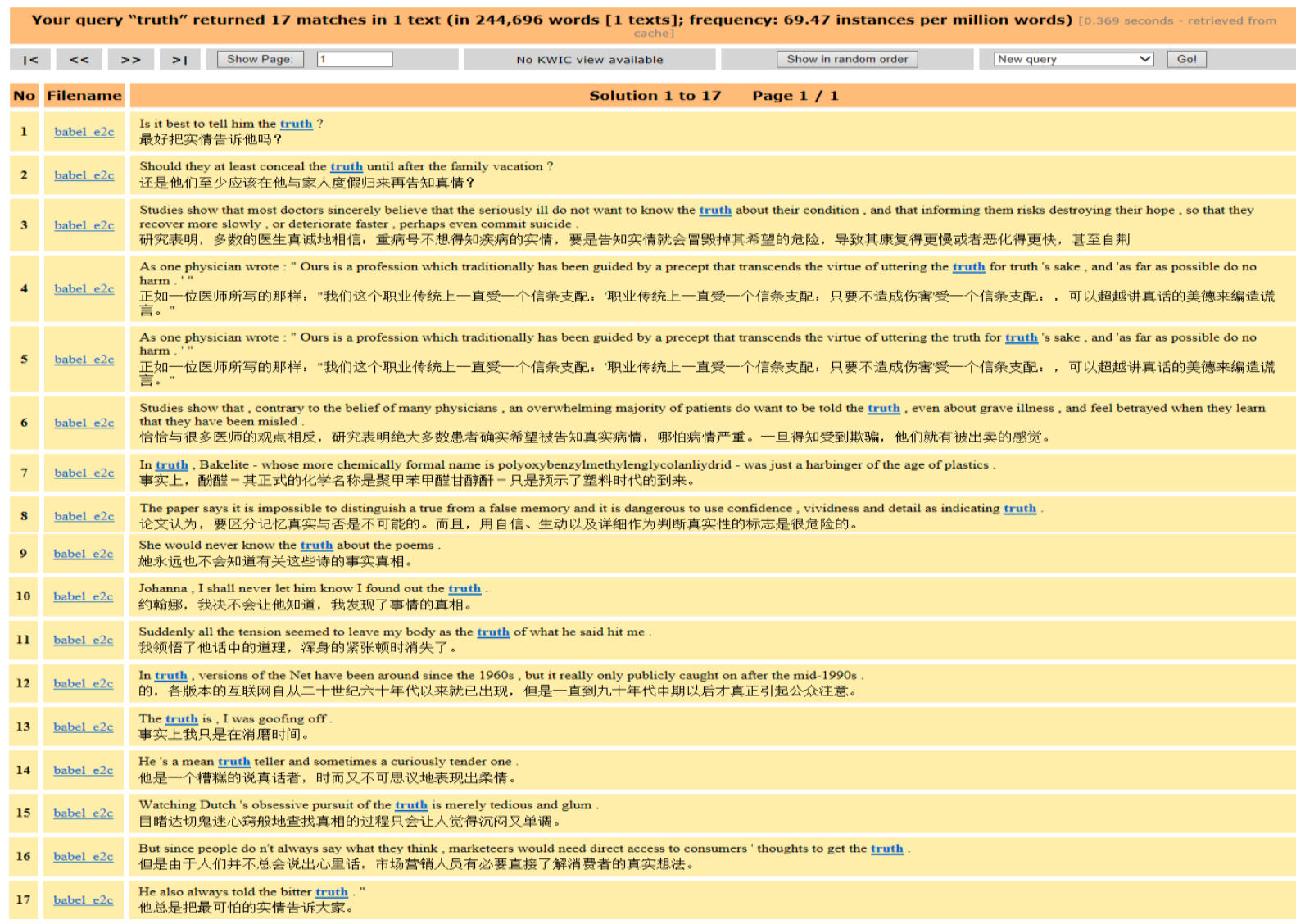

Of the seventeen examples found in the parallel corpus, "truth" is mostly rendered in Chinese as 实情[shí qíng], 真 情[zhēn qíng], 真相[zhēn xiàng], 事实[shì shí], meaning the fact, the real situation, and what happened, etc.. Maybe confined to the size of the corpus, 真理[zhēn lî] as the equivalent of "truth" rendered in most Chinese versions of the opening remark of Pride and Prejudice was not found in this corpus. Therefore, we resorted to the search for the

English equivalents of 真理[zhēn lī] in the same corpus, and got only one result as follows (Graph 3, below):

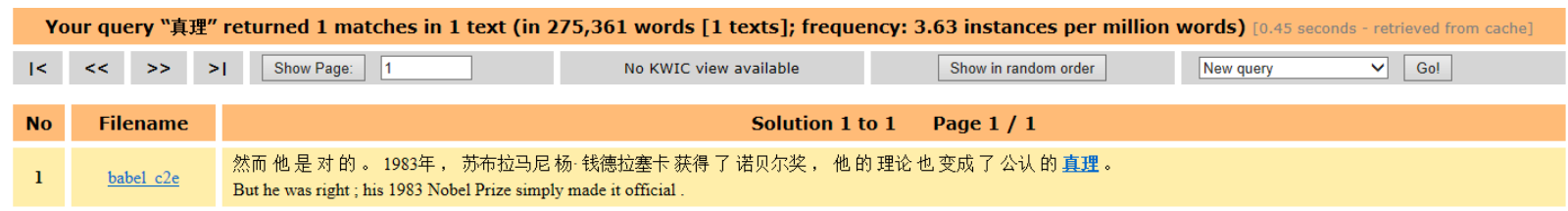

A liberal strategy was adopted in the translation of the original sentence, and no English equivalent of 真理[zhēn lị̌] was found in this corpus.

Under such circumstances, we resorted to monolingual corpora of both English and Chinese to find the concordances of the word "truth" in English and 真理[zhēn lǐ] in Chinese to know the meaning of them in a large number of examples and extended contexts. With SearchEngine, we found 8,368 concordances of the word "truth" in BNC, most of which meaning real situation, or what happened as mentioned above. Very few of them could be translated into 真理[zhēn lǐ] as in the sentence in question (Graph 4 \& 5 below) 
Query truth 8,386 (74.64 per million) (i)

Page 1 of 420 Go Next I Last

Written bo... of a pavement, we will not be far from the truth . At Lockleys, Herts., for example, six types of Written bo... of discussion, dignity of life, stress on truth in scholarship, study in depth, no fear of Written bo... like him as long as you live." $\langle/ p\rangle\langle p>|$ will swear to the truth of that right now. Though it was not just his Written bo... see I should have left myself out. To tell you the truth , I wasn't at all pleased about Russell sitting Written mi... through sieves into stone water jars, and if the truth were told, it was probably not very alcoholic Written mi... elsewhere, were discovering some home truths about quality control and the merits of Written mi... must, therefore, take account of the central truths of the Catholic faith and present the rest in Written mi... the rest in proper perspective. $\langle/ p\rangle\langle p\rangle$ These central truths are: * the mystery of God, the Father, the Son and Written bo... like presupposition, illocutionary force, truth condition to sentences or utterances, Written bo... statements, and thus can sensibly be assigned truth conditions (as philosophers have long noted; Written bo... years old These facts seem to establish that truth conditions must be assigned to utterances, Written bo... , not to sentences alone (or, if one likes, truth conditions include context conditions). So Written bo... semantics then one is forced to state truth conditions on sentences-in-contexts, or if Written bo... , say, with the recursive assignment of truth conditions to well-formed formulae, so Written bo... semantics is to be truth-conditional, then the truth conditions can only be assigned to utterances, Written bo... $\quad$. The sentence can only be assigned the right truth conditions, or alternatively be given the Written bo... $\quad$ that A was a male superior (that would make truths relative to whomsoever they are addressed). Written bo... the semantic content of a sentence with its truth conditions, then the semantic content of (4) Written bo... $\quad$ individual who was the mother of Napoleon. The truth of (4) in no way depends on who says it, but simply Written bo... ) I am the mother of Napoleon We cannot assess the truth of this sentence without taking into account Page 1 of 420 Go Next I Last

truth $\quad$ Q

Query truth 8,386 (74.64 per million) (i)

First I Previous Page 3 of 420 Go Next I Last

Spoken con... it's title is: Scientific Research, the Whole Truth, er and if you like I will draw the points out of Spoken con... n't it? Erm. I think there's supposedly, a lot of truth in it, really is there. I suppose there are, odd Spoken con... give that the evidence I shall give shall be the truth shall be the truth the whole truth the whole Spoken con... I shall give shall be the truth shall be the truth the whole truth the whole truth and nothing but Spoken con... Spoken con... Spoken con... Spoken con... Written bo... Written bo... Written bo... Written mi... Written mi... Written bo... Written bo... Written bo... Written bo... Written bo... Written bo... Written bo... shall be the truth shall be the truth the whole truth the whole truth and nothing but the truth and shall be the truth the whole truth the whole truth and nothing but the truth and nothing but the whole truth the whole truth and nothing but the truth and nothing but the truth thank you Mr take a seat and nothing but the truth and nothing but the truth thank you Mr take a seat would you keep your voice of 1858 brought any serious social unrest. The truth is that the great economic boom provided observed that 'the belief in philosophic truth has cooled off to such an extent that neither the - had its centre of gravity in Britain. The truth is that the social sciences reflected the persistence of an older and more fundamental truth . Data creation and data capture are at odds with ' and 'worst' scenario, acknowledging that the truth may often lie in-between. $\langle/ p\rangle\langle p\rangle$ At best, our record out of silence. Intruded in the syntax, truth interlards The structuring brain's concocted we miss sometimes the wit Only those who know the truth 's always Absconding can hit? The Bishop's face use for a generation, is faith In more than truth, for Jesting Pilate was inspired To ask the was inspired To ask the question of the Way, the Truth and the Life. The joke was on him, we presume. A have it off, though. No Innuendo - but doubtless truth in that. Two weeks later I'm taut on a clinical Perhaps there was more than a grain of truth in the remark of one of his closest colleagues conclude that there may, after all, be a grain of truth in the mischievous quip attributed to Oscar

First | Previous Page 3 of 420 Go Next I Last

Then we turned to MCC to look for the sentences containing the word 真理[zhēn lĩ], with 754 entries found from this corpus: Graph 6 (below) 


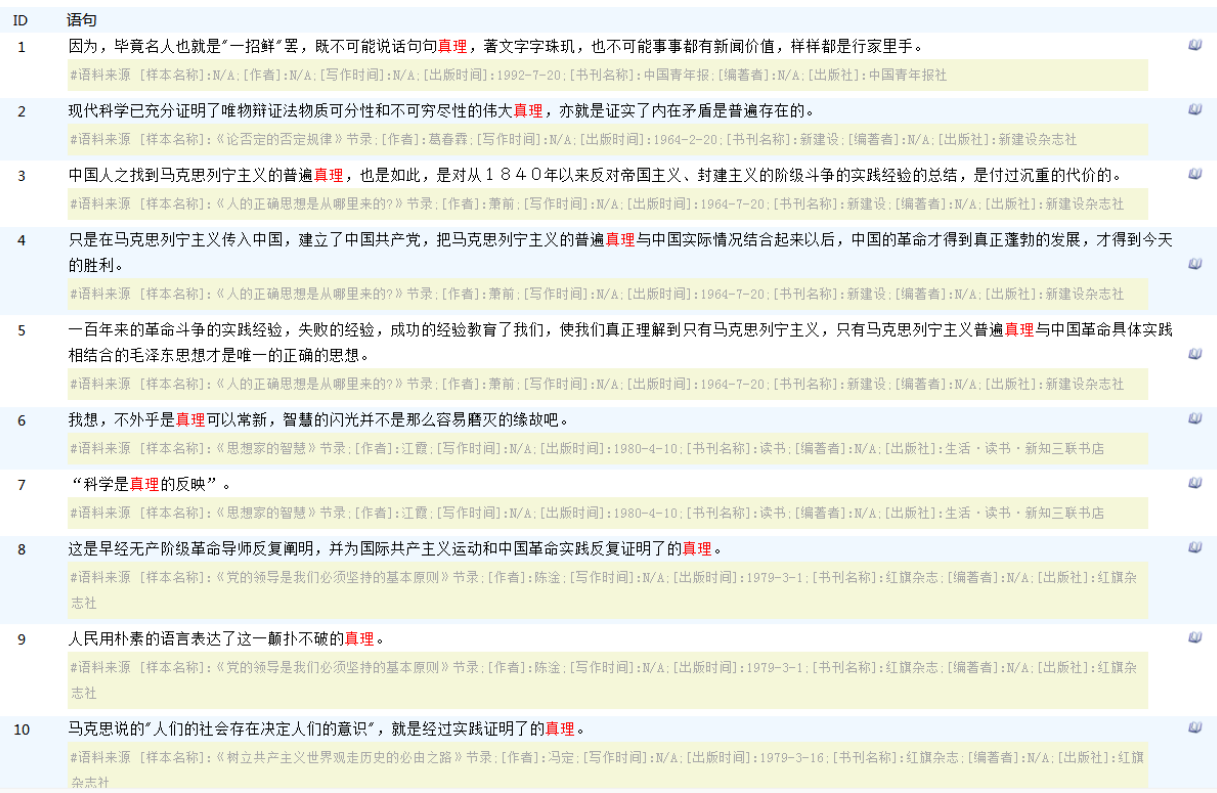

The concordances in Chinese provided us with the various contexts in which 真理[zhēn lî] was used. It can be seen from the examples that in some contexts, 真理[zhēn lî] means "truth," while in a lot of other cases, it refers to the objective things and their law of existence that are reflected in people's mind. In the opening remark, "It is a truth universally acknowledged, that a single man in possession of a good fortune must be in want of a wife," "a single man in possession of a good fortune must be in want of a wife" is a truth universally acknowledged, but is not necessarily 真理 [zhēn lĩ even though it is the choice of a dominant number of the translators. What Austen talks about is a social phenomenon that exists in societies of various cultures. In the concordances found in MCC, the word 真理[zhēn lî] is mostly associated with such words as "science," "practice," and "attest," etc. The practice is the one, and the only one criterion by which 真理[zhēn lĩ] is attested. This expression is frequently used in Chinese discourses. Here 真理[zhēn lî] refers not only the fact or the real situation but also the law lying behind the fact or genuine concern.

From the above exploration of the corpora's examples and context, the word "truth" here can be paraphrased as "an established idea" or a kind of concept or phenomenon that has been generally recognized. Based on such a judgment, it was assumed that the dominant 真理[zhēn lī] did not seem to be an appropriate equivalent of "truth."

\section{The equivalent of "must."}

Of the thirteen versions of the opening remark of the Pride and Prejudice, four translators rendered the word "must" as 总 (zǒng), five for 必定(bì dìng), three for 一定(yī dìng), and the remaining one for 势必 (shì bì) as listed above.

As an auxiliary verb, "must" means (1) to be obliged or bound to by an imperative requirement; (2) to be under the necessity to; (3) to be required or compelled to. As per the above equivalents, 总 (zǒng) means the tendency or general trend, while 必定(bì dìng) and 一定(yī dìng) are very close in terms of meaning. By standard query of these words in Babel Parallel Corpus (cn->en), we got the concordances (with a few examples shown below), which provided us with some clues to determine the appropriate equivalent of "must." Graph 7 (below)

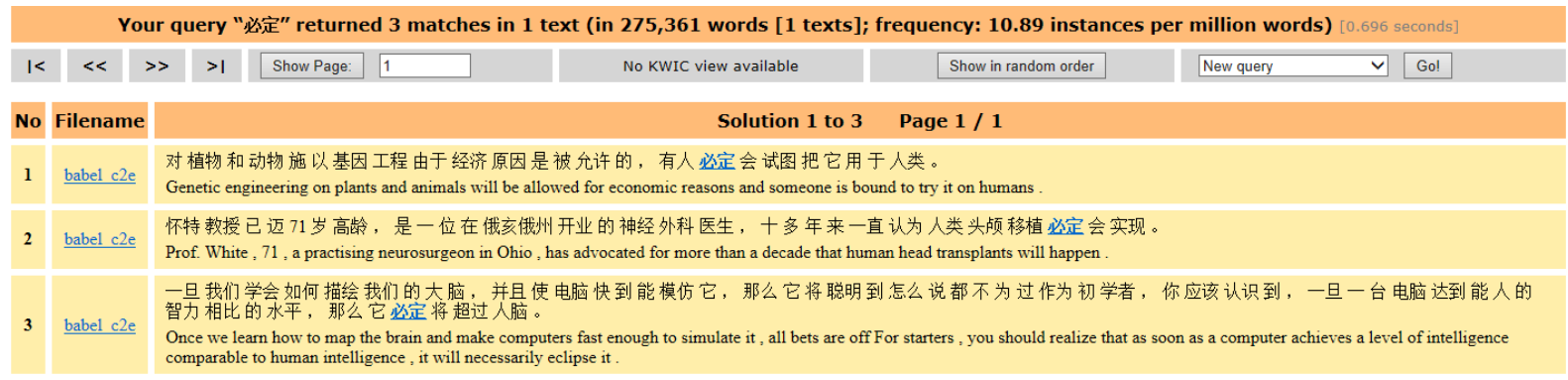

Graph 8 (below)

68 babel c2e

只要有一个零售商有我想要的鞋, 我想我们双方二定都能满意而归。

Should the right retailer match me up with the right pair of shoes, the retailer and I will both go home happy 
Graph 9 (below)

\begin{tabular}{|c|c|c|c|c|c|c|c|c|c|c|}
\hline \multicolumn{11}{|c|}{ Your query "势必" returned 2 matches in 1 text (in 275,361 words [ 1 texts]; frequency: 7.26 instances per million words) [0.545 seconds] } \\
\hline $1<$ & $\ll$ & $\gg$ & $>1$ & Show Page: & 1 & No KWIC view available & Show in random order & New query & $\checkmark$ & Go! \\
\hline No & \multicolumn{2}{|c|}{ Filename } & \multicolumn{8}{|c|}{ Solution 1 to 2 Page $1 / 1$} \\
\hline 1 & \multicolumn{2}{|c|}{$\underline{\text { babel c2e }}$} & \multicolumn{8}{|c|}{$\begin{array}{l}\text { 他们势必尽一切可能来保全这种表面形象，却很少会去培养自己内在的价值和注重个人的成长。 } \\
\text { Inevitably they will do everything they can to preserve this facade, but they will do very little to develop their inner value and personal growth. }\end{array}$} \\
\hline 2 & \multicolumn{2}{|c|}{$\underline{\text { babel } c 2 \mathrm{e}}$} & \multicolumn{8}{|c|}{$\begin{array}{l}\text { 我心想, 如果 隆格获胜, 那势必给 纳粹的 " 优等民族"（雅利安人优异）论调 增加 新 的佐证。 } \\
\text { I guessed that if Long won, it would add some new support to the Nazis' "master race' ( Aryansuperiority) theory. }\end{array}$} \\
\hline
\end{tabular}

From the concordances of 必定(bì dìng), we can see that it means something that would “surely" or necessarily happen. The query of 一定(yī dìng) returned 85 matches, but since most of them meant “to a certain extent," so they were not exactly what we wanted. The context of 势必 (shì bì) indicates the meaning of "something will happen inevitably" or would happen. In some sense, this corpus did not provide valuable information for differentiating the purpose of the translators' several words, respectively. Creative thinking should be mobilized to determine which of the four renderings was the most appropriate. It is generally believed that a physically, psychologically, and mentally healthy man will want or need a wife, which is quite natural in Western and oriental cultures. In Chinese culture, a single man in possession of a good fortune is usually under more necessity to have a wife than a single man without much wealth. A good fortune could consist of a large house or villa, or several houses or villas, various assets for maintenance, many servants to be supervised, etc., all of which need a capable person to maintain the smooth operation of the whole family. From this sense, 一定 $(y \overline{1}$ dìng) and 势必 (shì bì) seem to be the better equivalents in such a context.

\section{The equivalent of "be in want of"}

From Figure 1 in section 4.3, we knew that, out of the thirteen Chinese versions, six translators rendered 想/想要 (xiăng/xiăng yào) as the equivalent of the phrase "be in want of." Through back translation, 想/想要 (xiăng/xiăng yào) just meant "want" in Chinese, meaning "feel a need or a desire for" or "wish or crave for something." Let us first have a look at the historical development of the usage of this phrase in COHA. Graph 10 (below)

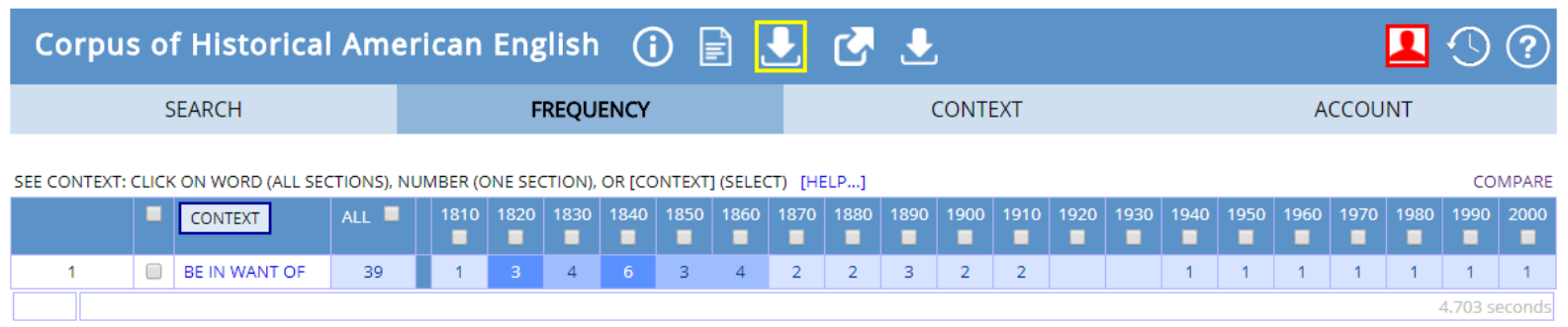

The above graph shows the frequency of "be in want of" in nearly two hundred years from 1810 to 2000 . It can be seen that this phrase has a lower frequency of use in history, starting from ONE in 1810 and reaching the highest of SIX in 1840. After that, it has been decreasing ever since. A few examples shown below provide us with the time and context of this phrase (Graph 11 below).

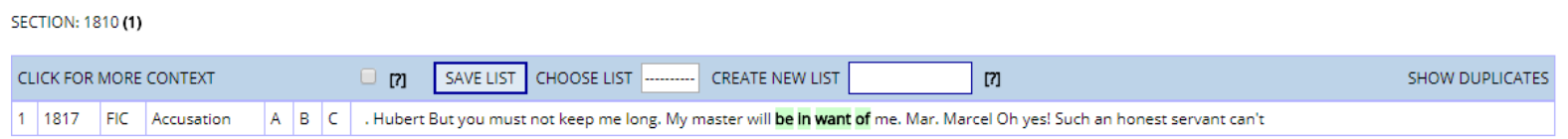

Graph 12 (below)

\begin{tabular}{|c|c|c|c|c|c|c|c|c|c|}
\hline \multicolumn{6}{|c|}{ CLICK FOR MORE CONTEXT } & \multicolumn{2}{|c|}{$\square[]$} & 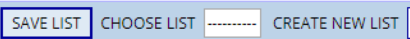 & SHOW DUPLICATES \\
\hline 1 & 1841 & FIC & JulianScenesin & A & B & c & \multicolumn{3}{|c|}{ one part of which it is carved out. If the omnipotent Tiberius be in want of money, let the Greeks of Csarea make a contribution of such pence as } \\
\hline 3 & 1842 & FIC & GrandfathersChair & A & B & c & \multicolumn{3}{|c|}{ allowed to keep possession of this beautiful country till the white men should be in want of it. " " Did the pious men of those days never try to } \\
\hline 4 & 1847 & FIC & Omoo & A & B & c & \multicolumn{3}{|c|}{ to be lying in the harbour, wooding and watering, and to be in want of men. All things considered, I could not help looking upon Taloo as } \\
\hline 5 & 1847 & FIC & AroundTheTea-Table & A & B & c & \multicolumn{3}{|c|}{ we do not see that any church in city or country need long be in want of poor preaching. CHAPTER XXIX. SHELVES A MAN'S INDEX. In Chelsea } \\
\hline
\end{tabular}

From the contexts provided here, it seems that the phrase means "feel a desire for," while in other contexts, it means "need." So it is necessary to resort to corpora to investigate its usage further. 
Through the function of "Word Sketch" in Sketch Engine, we used "want" as the lemma and found the following results in BNC (Graph13, below).

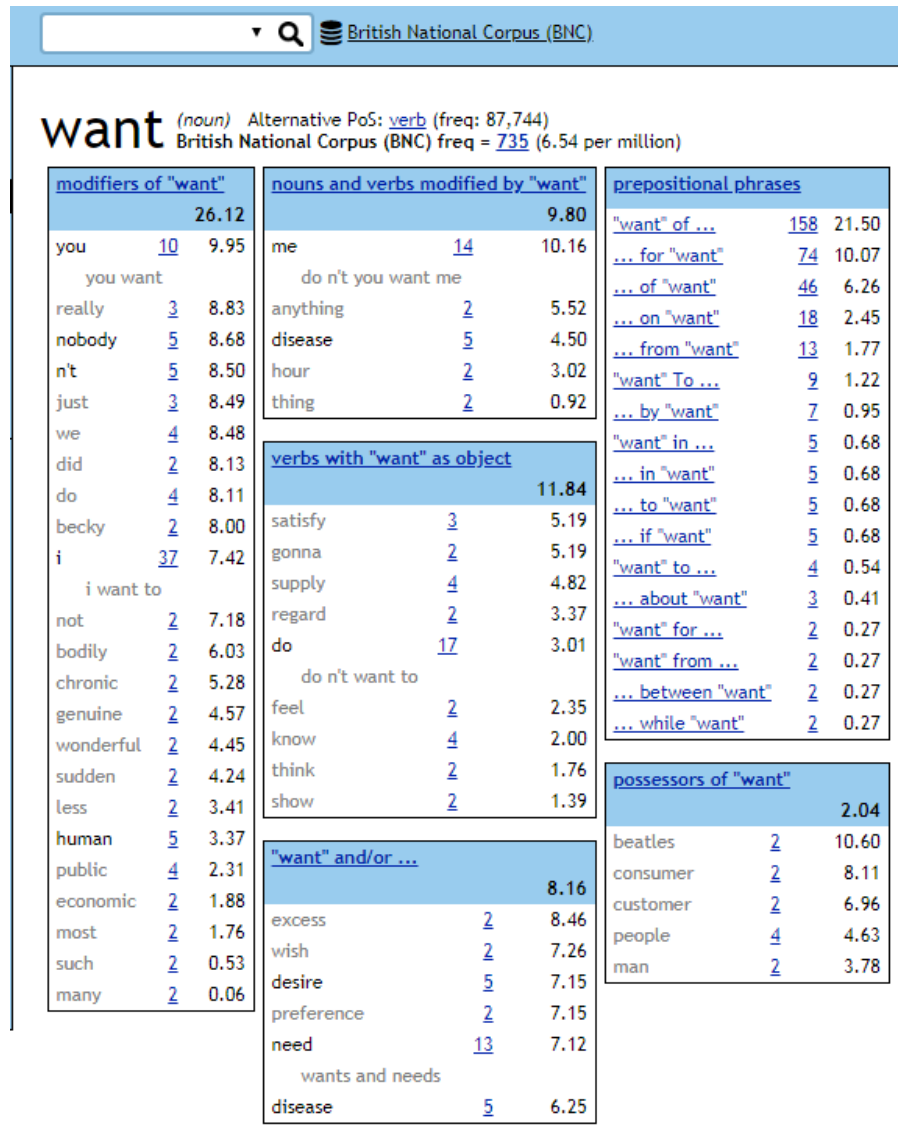

In the Prepositional Phrases, 158 cases of "want of," and some concordances are shown as follows (Graph 14, below):

\section{- $\mathbf{Q}$ B British National Corpus (BNC)}

\section{Query 158 (1.41 per million) (i)}

First I Previous Page 3 of 8 Go Next I Last

Written bo... $\quad$ and this again started the discussion" For the want of a bridge here at Halling" to quote Lambarde. Spoken con... because the green and the erm er, this, th for want of a better colour, it's really red, it's a sort Spoken con... the fact of erm $s$ solidarity $\mathrm{fr}$ fr from want of a better word. Yeah. Erm was it in your opinion Spoken con... $\quad$. I think if you let development rip for the want of a better word in North Yorkshire, as I suggest Written bo... 'exceptional talent, which is sterilised for want of educational opportunities '. The Spoken con... erm, we called it the ticket book, that was for want of some other name I suppose. It was the record Spoken con... $\quad$. All those positions were going for want of an application, so I applied and because Written bo... simplicity of their lines but not 'Cubist' for want of a better term ; easy on the eye and bottom; they Written bo... $\quad$, and certainly the police did not suffer for want of legal powers . Although some specific Written bo... welfare of numbers are hazarded and ruined for want of an inclosure .' They certainly were a rough Written bo... for Holland in Lincolnshire lamented 'the want of gentlemen here to inhabit.

Written bo... my eyes when it was dark and feeling a sudden want of air opened the window when to my astonishment Written bo... her happy? She felt, in her new severity (for want of a better word) only half alive, she knew she Written bo... $\quad$ : 'What an excellent horse do they lose for want of skill and courage to manage him!' Philip at Written bo... do something now, because perhaps it was for want of normal company that Eleanor Thorne lay until Written bo... complained that there was great disorder 'for want of a swanmote court '. James therefore ordained Written bo... Eye Of Students in Physiognomy; Who read your want of Wit or Grace, Not from your Manners, but your Written mi... the course of time, but they thereby show their want of ability to observe correctly. I dissolved a Written bo... to the railway with its reliable timetable for want of proper information about road services. $\langle/ p\rangle$ Written bo... restaurants. It found, high prices; a frequent want of authenticity in purportedly French cuisine

First I Previous Page 3 of 8 Go Next I Last 
The concordances are indicators of the frequency of the phrase "for want of," which means "for lack of" or "for lacking in." A broader context is provided here as an example in graph 15 (below):

\section{$\Downarrow$}

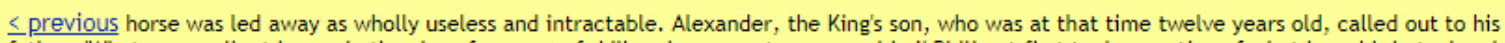
father: 'What an excellent horse do they lose for want of skill and courage to manage him!' Philip at first took no notice of what he said; but when he heard him repeat the same thing several times, and saw he was greatly upset by the next?

In the full sentence here, "What an excellent horse do they lose for want of skill and courage to manage him!" the word "want" means "lack or deficiency." Then still in BNC, the search for collocates of "in want of" produced only one concordance. The phrase here actually means "be in need of," which is one of the renderings of the thirteen Chinese versions of the opening remark in Pride and Prejudice. (see Graph 16 below)

\begin{tabular}{|c|c|c|c|}
\hline British Nationa & (C) (i) & & \\
\hline SEARCH & FREQUENCY & CONTEXT & ACCOUNT \\
\hline
\end{tabular}

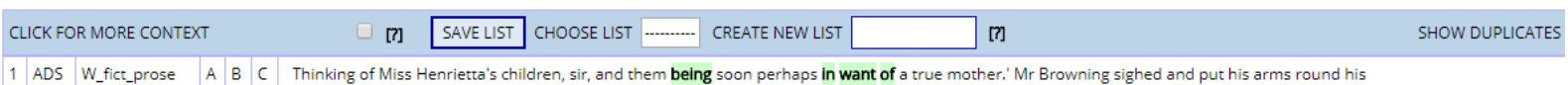

To have more supportive information, we went back to The Babel English-Chinese Parallel Corpus, and through the query of "want," we got 265 matches, as shown in Graph 17 (below):

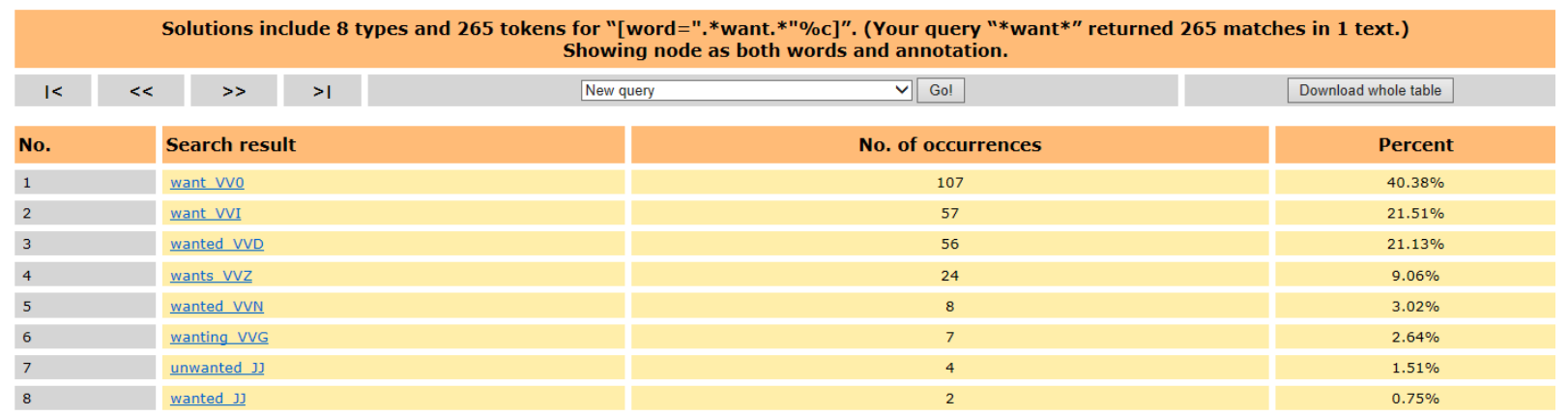

This graph shows the number of occurrences of the word "want" used in different phrases. In Wanting VVJ structure, only one example was found, in which “wanting in” means 缺乏[quē fá] (be lack of, be deficient of) (see Graph 18 below).

3 babel e2c Wanting in perseverance, such volatile natures are outstripped in the race of life by the diligent and even the dull

3 babel e2c 缺乏了毅力, 那些反复无常的人就会在生存竞争中被勤奋甚至迟钝的人所超越。

Furthermore, we again searched for the full phrase "be in want of" in BNC, and got the same sentence as Pride and Prejudice. (Graph 19 below)

\section{be in want of $\quad \mathbf{Q}$ 三 British National Corpus (BNC), tagged by CLAWS}

\footnotetext{
Query be, in, want, of 3 ( 0.03 per million) $\mathbf{i}$

Imaginativ... a single man in possession of a good fortune must be in want of a wife.' Wexford smiled grimly to himself. $\langle/ p\rangle$ Imaginativ... a single man in possession of a good fortune must be in want of a wife,' said James. $\langle/ p\rangle\langle p\rangle$ 'I'm not going to argue with Arts a single man in possession of a good fortune must be in want of a wife.' She must have been thinking of Steven (
}

Sometimes, due to choice and coverage of materials, one corpus always has some limitations. As a complement, we resorted to COCA, and happily got more contexts of the phrase "be in want of" ranging from 1990 to 2017(see Graph 20 as follows). 


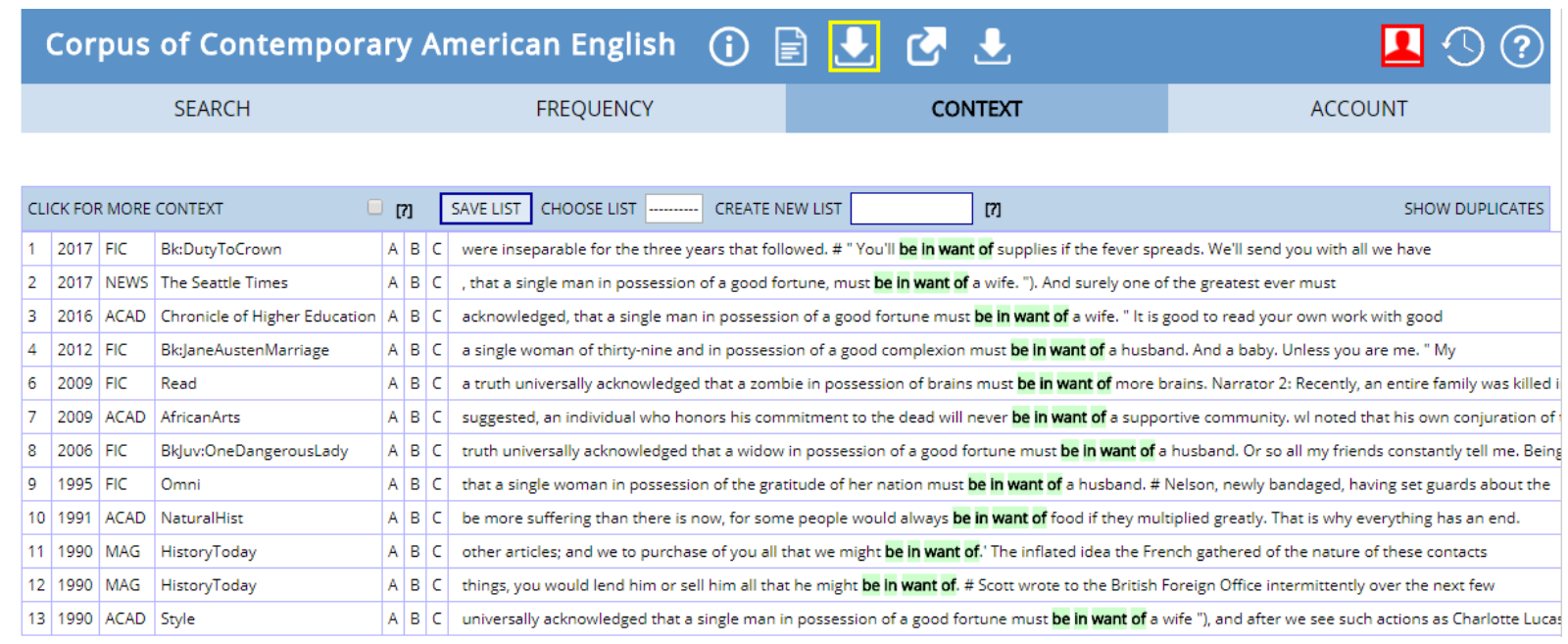

From these concordances above, we knew that "be in want of" mostly means "be in need of," which can be rendered as 需要 $[x \bar{u}$ yào] instead of 想要 (xiăng/xiăng yào) in Chinese, as four translators did in the translation of the opening remarks in Pride and Prejudice. Just as what has been analyzed in this paper, it is quite natural for any healthy man to be looking forward to a wife, whereas in real life, a man of a good fortune is usually considered to be under more necessity to find a wife at least this is the case in Chinese culture. In other words, this is just like the relationship between a dream and reality. So 需要 $[x \bar{u}$ yào] is more appropriate than 想要 (xiăng/xiăng yào) in this context.

\section{A new version of the translation}

The search results from the comparable parallel corpus and the monolingual corpora have enabled us to have a very close look at the meaning of the keywords and phrases such as "truth," "must," and "be in want of" in the opening remark of Pride and Prejudice of Jane Austen. Therefore, we have had a thorough analysis of the equivalents' appropriateness of these words and phrases in Chinese as rendered by the selected thirteen versions. However, we should by no means be saturated with the analysis and appreciation. By assuming critical and creative thinking, we would like to propose another version of the opening remark:

家财万贯, 单身男子, 一定得有位贤妻内助, 这在哪里都毫不稀奇。

jiā cái wàn guàn, dān shēn nán zǐ, yī ding děi yǒu wèi xián qī nèi zhù, zhè zài nă lǐ dōu háo bù xī qí.

\section{CONCLUSION}

It can be concluded from the above discussion and analysis of the thirteen versions of the opening remark of Pride and Prejudice with the help of corpora that:

(1) Corpora, with a large number of concordances providing many more examples and extended contexts, are useful and powerful tools and sources for translation practice as well as translation training;

(2) It should be noted that each corpus has its limitations due to its size, representation, and coverage for its specific purposes of design;

(3) Because of the nature of corpora, there are generally no explanations for particular words or phrases. Therefore, they should be used in combination with dictionaries, both of which can complement each other;

(4) Some, at least from my judgment and analysis, inappropriate translations of the words and phrases investigated here, such as "truth," "must," and in particular, "be in want of," are the result of the fact that these words and phrases seem too simple to be treated seriously. Therefore, some translators might take it for granted and produce the commonly matching equivalents from their minds quietly naturally;

(5) Novice translators are mostly likely to make such mistakes, moving an entry from the dictionary into their translation without trying to think hard to find a more appropriate equivalent based on the entries in the dictionary;

(6) Therefore, it is crucial in corpus-aided translation practice and translation teaching that translators or teachers should assume critical and creative thinking in corpora use. On the one hand, we can take advantage of the resources provided by various corpora, and on the other hand, we should not rely too much on corpora. Human judgment should be mobilized in the evaluation of the appropriateness of translation, especially those keywords and phrases;

(7) Lastly, as translation teachers, we should also consider that enhancing student translators' competence through constant practice is still the priority in teaching or training activities; otherwise, students are much likely to be confused in front of such powerful tools as corpora.

\section{REFERENCES}

[1] Aranda, L. V. (2009). Forms of creativity in translation. Cadernos De Tradução, 1(23), $23-37$.


doi:10.5007/2175-7968.2009v1n23p23.

[2] Baker, Mona. (1993). Corpus Linguistics and Translation Studies: Implications and Applications. In Mona Baker et al. (eds). Text and Technology. Philadelphia and Amsterdam: Benjamins.233-250.

[3] Baker, M., \& Malmkjaer, K. (1998). Routledge encyclopedia of translation studies. London: Routledge.

[4] Ballesteros, L., \& Croft, W. B. (1998, August). Resolving ambiguity for cross-language retrieval. In Proceedings of the 21st annual international ACM SIGIR conference on research and development in information retrieval (pp. 64-71). ACM.

[5] Bowker, L. (1999). Exploring the potential of corpora for raising language awareness in student translators. Language Awareness, 8(3-4), 160-173. doi:10.1080/09658419908667126.

[6] Bowker, L. (2000). A corpus-based approach to evaluating student translations. Translator: Studies in Intercultural Communication, 6(2), 183-210. doi:10.1080/13556509.2000.10799065.

[7] Faber, P. (1998). Translation competence and language awareness. Language Awareness, 7(1), 9-21. $10.1080 / 09658419808667097$.

[8] Granger, S. (2003). The international corpus of learner English: A new resource for foreign language learning and teaching and second language acquisition research. TESOL Quarterly, 37(3), 538-546. 10.2307/3588404.

[9] Hartmann, R. R. K. (1994). The use of parallel text corpora in the generation of translation equivalents for bilingual lexicography. Martin, W. et al. (eds.), 291-297.

[10] Hewson, L. (2016). Creativity in translator training: Between the possible, the improbable and the (apparently) impossible. Linguaculture, 2016(2), 9-25. doi:10.1515/lincu-2016-0010.

[11] Ivanova, O. (2016). Translation and ICT competence in the globalized world. Procedia - Social and Behavioral Sciences, 231, 129-134. 10.1016/j.sbspro.2016.09.081.

[12] Kisiel, T. (1990). The creativity of translation and its universality in the hermeneutic process. Bulletin De La Société Américaine De Philosophie De Langue Française, 2(3), 142-151.

[13] Kussmaul, Paul (1995). Training the Translator. Amsterdam/Philadelphia: John Benjamins.

[14] Laviosa, S. (2002). Corpus-based translation studies: Theory, findings, applications. New York; Amsterdam; Rodopi.

[15] Laviosa, S. (2004). Corpus-based translation studies: Where does it come from? where is it going? Language Matters, 35 (1), 6-27. doi:10.1080/10228190408566201.

[16] Leech, G., Garside, R. \& Bryant, M. (1994). The large-scale grammatical tagging of text: Experience with the British National Corpus. In Oostdijk, N. \& de Hann, P. (eds) Corpus-based Research into Language: In honor of Jan Arts. Amsterdam/Atlanta: Rodopi. 47-61.

[17] Newmark, Peter. (1991). About Translation, Buffalo: Multilingual Matters Ltd.

[18] Pym, A. (2003). Redefining translation competence in an electronic age. in defense of a minimalist approach. Meta, 48(4), 481-497. 10.7202/008533ar.

[19] Pym, A. (2011). What technology does to translating. The International Journal for Translation \& Interpreting Research, 3(1), $1-9$.

[20] Robin, E., Götz, A., Pataky, É., \& Szegh, H. (2017). Translation studies and corpus linguistics: Introducing the pannonia corpus Acta Universitatis Sapientiae, Philologica, 9 (3), 99-116. doi:10.1515/ausp-2017-0032.

[21] Sinclair, J.M. (1992). "The Automatic Analysis of Corpora." Directions in Corpus Linguistics. Proceedings of Nobel Symposium 82, Stockholm 4-8 August 1991 ed. By J. Svartvik 379-97. Berlin and New York: Mouton de Gruyter.

[22] Tiedemann, J. (1998). Extraction of translation equivalents from parallel corpora. In Proceedings of the 11th Nordic Conference of Computational Linguistics (NODALIDA 1998) (pp. 120-128).

[23] Tymoczko, M. (1998). Computerized Corpora and the Future of Translation Studies. Meta, 43(4), 652-660. doi:10.7202/004515ar.

[24] Wang Yan (2007). Corpus Search and Analysis of Pride and Prejudice, Journal of Jiangsu Institute of Education (Social Science), Vol. 23. No.2. 100-102.

[25] Wang Hui. (2015). Application of "Highly Processed" Parallel Corpus in Translation Teaching. Journal of Chinese Translators. Issue 1: $50-54$

[26] Zanettin, F. (1998). Bilingual Comparable Corpora and the Training of Translators. Meta, 43(4), 616-630. doi:10.7202/004638ar

Qingliang Meng is a Ph.D. candidate at the School of Languages, Cultures and Linguistics, University College Dublin (UCD), Ireland. He received his M.A. by research degree from Donghua University, Shanghai, China. He is a lecturer of English in Jiaxing University, Zhejiang province, China. His research interests include second language acquisition, translation and interpreting studies, corpus linguistics, psycholinguistics, business English, intercultural communication, etc. 